\title{
The effect of variation in dietary protein or mineral supply on calcium and phosphorus metabolism in lactating ewes
}

\author{
BY A. A. J. RAJARATNE*, D. SCOTT $\dagger$, W. BUCHAN AND A. DUNCAN \\ Rowett Research Institute, Bucksburn, Aberdeen AB2 9SB
}

(Received 1 September 1989 - Accepted 9 February 1990)

\begin{abstract}
Two experiments are described in which changes in both nitrogen and mineral balance were monitored in ewes during lactation. In Expt 1 , two groups $(n$ 6) of ewes were fed on diets that were either high (15 $\mathrm{g}$ crude protein $(\mathrm{N} \times 6.25 ; \mathrm{CP}) / \mathrm{MJ}$ metabolizable energy (ME)) or low $(10 \mathrm{~g} \mathrm{CP/MJ} \mathrm{ME)} \mathrm{in} \mathrm{protein}$ content, and concurrent $\mathrm{N}$ and mineral balance studies were made at intervals during lactation with ${ }^{45} \mathrm{Ca}$ and ${ }^{32} \mathrm{P}$ being used to monitor faecal endogenous calcium and phosphorus losses. Ewes fed on the highprotein diet maintained a positive $\mathrm{N}$ balance during early lactation, whereas those fed on the low-protein diet were in negative $\mathbf{N}$ balance. Both groups, however, showed the same degree of negative $\mathbf{C a}$ and $\mathbf{P}$ balance, with the amounts lost being directly related to milk yield. This indicates that loss of mineral from the skeleton at this time is not secondary to a loss of bone matrix due to a shortfall in dietary protein supply. In Expt 2, two groups of ewes $(n 4)$ were fed on diets in late pregnancy that were either just adequate or generous in Ca and $P$ supply relative to requirement (TCORN, 1990). After parturition both groups were fed on a diet which was formulated to meet their estimated $\mathrm{Ca}$ and $\mathrm{P}$ requirements for lactation. As in the previous experiment both groups were in negative $\mathrm{Ca}$ and $\mathrm{P}$ balance in early lactation and variation in dietary $C a$ and $P$ supply during pregnancy had no effect on the extent of this loss. Alternative explanations for the cause of this loss of mineral from the skeleton are discussed.
\end{abstract}

Calcium metabolism : Phosphorus metabolism: Lactation: Sheep

Sheep and cattle are known to lose appreciable amounts of calcium and phosphorus from their skeletons during early lactation (Braithwaite et al. 1969; Braithwaite, 1983a,b; Ramberg et al. 1970). The reason for this is not clear though the amounts lost do seem to be dependent on milk yield and do not appear to be greatly influenced by variations in current dietary $\mathrm{Ca}$ and $\mathrm{P}$ supply (Braithwaite, 1983a,b).

Supply during pregnancy may, however, play a part, with loss of mineral from the skeleton during early lactation being reportedly greater in ewes fed on a diet high in $\mathrm{Ca}$ during pregnancy (Braithwaite, 1978). A deficiency in energy and protein supply relative to lactation needs may also be a factor. This in practice arises due to a shortage of high-quality feed on many farms and an inability on the part of the animal to consume enough of a lower quality feed to satisfy its energy and protein requirements (Forbes, 1977). In these circumstances it has been suggested that loss of mineral from bone may be secondary to a loss of bone matrix resulting from this shortfall in protein supply (Sykes \& Geenty, 1986).

The work described here was designed to test these possibilities in lactating ewes and involved concurrent nitrogen and mineral balance studies and the use of pyridinoline and deoxy-pyridinoline excreted in the urine as markers of bone-protein turnover (Black et al. 1988).

* Present address : Department of Physiology, Faculty of Medicine, The University of Peradeniya, Peradeniya, Sri Lanka.

$\dagger$ For reprints. 


\section{EXPERIMENTA L}

Animals and diets

Twenty Finnish Landrace $\times$ Dorset Horn ewes, averaging about $70 \mathrm{~kg}$ live weight, were used in two experiments involving twelve and eight ewes respectively. Each group was hormone-treated (chronogest intra-vaginal sponges, Intervet UK Ltd) in order to control oestrous activity and synchronize conception.

Two pelleted diets were used and details of their composition are given in Table 1. The first diet (low-protein diet) was designed to supply about $10 \mathrm{MJ}$ metabolizable energy (ME) and $100 \mathrm{~g}$ crude protein $(\mathrm{N} \times 6.25 ; \mathrm{CP}) / \mathrm{kg}$ dry matter $(\mathrm{DM})$, and the second (high-protein diet) about $10 \mathrm{MJ} \mathrm{ME}$ and $150 \mathrm{~g} \mathrm{CP} / \mathrm{kg} \mathrm{DM}$. Both diets were formulated so as to supply the same amounts of $\mathrm{Ca}$ and $\mathrm{P}$, though on analysis the low-protein diet was found to contain rather more of these minerals (Ca $4 \cdot 16 ; \mathrm{P} 3.49 \mathrm{~g} / \mathrm{kg} \mathrm{DM}$ ) than the high-protein diet (Ca $3.63 ; \mathrm{P} 3.27 \mathrm{~g} / \mathrm{kg} \mathrm{DM}$ ). In both cases the levels supplied were sufficient to satisfy the ewes' requirements for these minerals according to TCORN (1990).

\section{Expt 1}

Twelve of the ewes were used. Of these two were carrying triplets, six were carrying twins while the other four carried a single lamb. At birth the triplets averaged $3.3 \mathrm{~kg}$, the twins $4.1 \mathrm{~kg}$ and the single lambs $4.5 \mathrm{~kg}$ live weight. During pregnancy the ewes were housed indoors and were fed on a general-purpose diet comprising $(\mathrm{g} / \mathrm{kg})$ : hay 500 , barley $299 \cdot 5$, molasses 100, white fishmeal 91, salt 3, dicalcium phosphate 5, trace mineral-vitamin supplement 1 (Norvite 317, Norvite Feed Supplements, Wardhouse, Insch, Aberdeenshire). Intake ranged from $1.2 \mathrm{~kg} / \mathrm{d}$ in early pregnancy to $1.8 \mathrm{~kg} / \mathrm{d}$ just before parturition. At $142 \mathrm{~d}$ of gestation parturition was induced by giving the ewes $16 \mathrm{mg}$ betamethasone by intramuscular injection (Betsolan, Glaxo Laboratories Ltd). After lambing the ewes were divided according to weight into two equal groups, one of which was fed on the low-protein diet and the other on the high-protein diet. After $2 \mathrm{~d}$ the lambs were removed and the ewes were then machine-milked for a further $90 \mathrm{~d}$, initially on a twice daily basis at 08.00 and 20.00 hours and then once daily at 08.00 hours once milk yield had fallen below $0.5 \mathrm{~kg} / \mathrm{d}$. Immediately before milking, each ewe was given an intravenous injection of $5 \mathrm{i}$.u. oxytocin (Intervet UK Ltd) to stimulate milk let down.

Concurrent $\mathrm{N}$ and mineral balance measurements were made during four periods covering days $14-25,36-47,57-68$ and $78-89$ after parturition, and during these periods the animals were housed in metabolism cages that allowed the separate collection of urine and faeces.

From parturition until the end of the first collection period food intake was held at $2.0 \mathrm{~kg} / \mathrm{d}$ and was then reduced to $1.7 \mathrm{~kg} / \mathrm{d}$ until the end of period 2 , and then down to $1.4 \mathrm{~kg} / \mathrm{d}$ until the end of the trial.

At the start of each collection period each ewe was given $0.25 \mathrm{mCi}^{45} \mathrm{Ca}$ as $\mathrm{CaCl}_{2} \cdot 2 \mathrm{H}_{2} \mathrm{O}$ in $10 \mathrm{ml}$ saline $\left(9 \mathrm{~g}\right.$ sodium chloride/l) and $0.45 \mathrm{mCi}^{32} \mathrm{P}$ as $\mathrm{Na}_{2} \mathrm{HPO}_{4}$ in $10 \mathrm{ml}$ isotonic phosphate buffer ( $\mathrm{pH} \mathrm{7.4)} \mathrm{via} \mathrm{a} \mathrm{jugular} \mathrm{catheter} \mathrm{at} 10.00$ hours. Both isotopes were supplied by Amersham International plc (Amersham, Bucks). Blood samples were collected at 2, 5, 10,15 and $30 \mathrm{~min}$ and at $1,1 \cdot 5,2 \cdot 5,3,4,5,6,7,8,10,12$ and $24 \mathrm{~h}$ after dosing and thereafter once a day at 10.00 hours. Urine was collected on a daily basis into a bucket containing $50 \mathrm{ml}$ sulphuric acid $(100 \mathrm{~g} / \mathrm{l})$. Each day's output was weighed and $2 \%$ was retained to provide a bulk sample for $\mathrm{N}$ and mineral analysis. Faeces were collected at six-hourly intervals for the first $72 \mathrm{~h}$ after isotope injection and thereafter daily at 10.00 hours. Each day's faeces were well mixed and $5 \%$ were retained to provide a bulk sample for $\mathrm{N}$ analysis 
Table 1. Expt 1. Composition of the low-and high-protein diets $(\mathrm{g} / \mathrm{kg})$

\begin{tabular}{lcc}
\hline \multicolumn{1}{c}{ Component } & Low-protein diet & High-protein diet \\
\hline Hay & 560 & 560 \\
Barley & 280 & 340 \\
Cassava & 105 & - \\
Blood meal & - & 45 \\
Molasses & 40 & 40 \\
Urea & 5 & 5 \\
$\mathrm{Na}_{2} \mathrm{SO}_{4}$ & 2 & 2 \\
$\mathrm{CaHPO}_{4} \mathrm{H}_{2} \mathrm{O}$ & 6 & 6 \\
Trace element + vitamin supplement* & 2 & 2 \\
\hline \hline
\end{tabular}

* Contained $(\mathrm{g} / \mathrm{kg})$ : calcium 184 , magnesium 100 , zinc $36 \cdot 4$, manganese $45 \cdot 5$, iodine $1 \cdot 3$, selenium $0 \cdot 1$, cobalt $2 \cdot 25$, retinol 3.0, ergocalciferol $0 \cdot 05, \mathrm{D}, \mathrm{L}-\alpha$-tocopherol acetate 40 .

while separate duplicate $100 \mathrm{~g}$ portions were also retained for mineral and radioisotope measurements. Milk yield was recorded daily with the evening milk being combined with that collected the following morning. From this mixed sample duplicate $5 \mathrm{ml}$ portions were taken for mineral analysis and a further $10 \%$ was retained for $\mathrm{N}$ analysis.

\section{Expt 2}

The other eight ewes were used and of these one was carrying twins and the remainder a single lamb with the lambs at birth averaging $4.56 \mathrm{~kg}$ live weight. For the first $50 \mathrm{~d}$ of pregnancy treatment of the ewes was as described previously. At this point they were divided by weight into two equal groups one of which was fed on a diet similar in composition to the high-protein diet used in the previous experiment but which was lower in $\mathrm{Ca}$ and $\mathrm{P}$ content $(2.88$ and $2.19 \mathrm{~g} / \mathrm{kg} \mathrm{DM}$ respectively) while the other group was fed on the same diet supplemented with $\mathrm{CaHPO}_{4} \cdot 2 \mathrm{H}_{2} \mathrm{O}$ so as to increase its $\mathrm{Ca}$ and $\mathrm{P}$ content up to 10.23 and $7.56 \mathrm{~g} / \mathrm{kg}$ DM respectively. As before, parturition was induced at $142 \mathrm{~d}$ of gestation and both groups of ewes were then fed on the same high-protein diet as used in Expt 1 . After $2 \mathrm{~d}$ the lambs were removed and the ewes were then machine-milked, with mineral balance measurements being carried out over two periods covering days 14-25 and 35-46 after parturition. The procedures used were as described previously and during both periods food intake was fixed at $1.8 \mathrm{~kg} / \mathrm{d}$.

\section{Analytical methods}

Ca levels in food, faeces, urine, milk and plasma were determined using a Technicon Autoanalyzer and the method of Gitelman (1967). Total P in these materials was determined using the method of Roach (1965) while inorganic P levels in plasma were determined using the method of Young (1966). $\mathrm{N}$ levels in food, faeces, urine and milk were determined by the Kjeldahl method as described by Davidson et al. (1970) while the levels of pyridinoline and deoxy-pyridinoline in urine were determined using the method of Black et al. (1988).

The levels of ${ }^{45} \mathrm{Ca}$ and ${ }^{32} \mathrm{P}$ in plasma and faeces were determined using a liquid scintillation counter (Packard $1900 \mathrm{CA}$ ) and the values were corrected for quenching using the external standard method. Plasma samples were deproteinized using trichloroacetic acid $(100 \mathrm{~g} / \mathrm{l})$ before counting while faeces were dry-ashed and the resulting ash was dissolved in concentrated nitric acid. 
A. A. J. RAJARATNE AND OTHERS

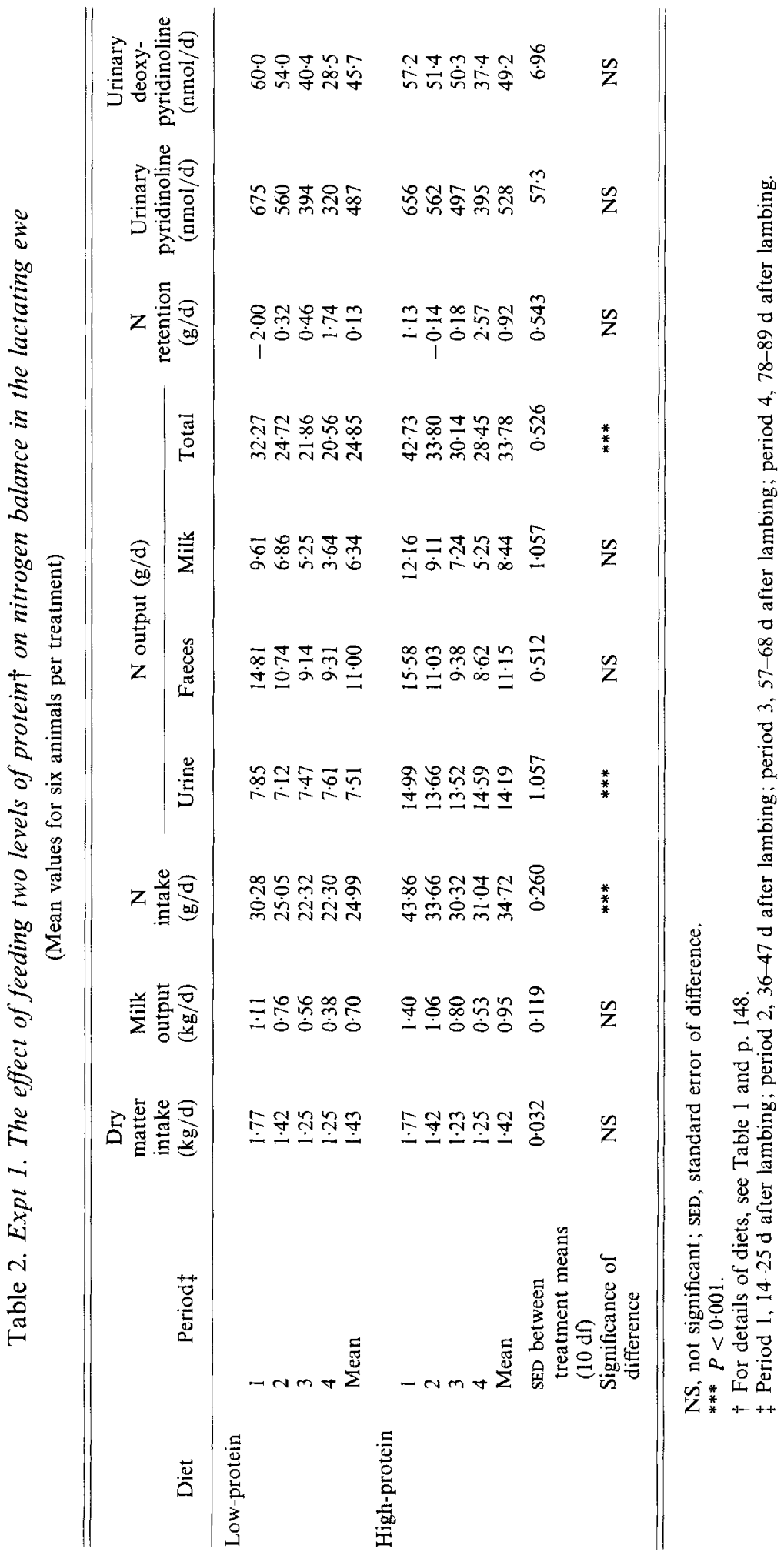




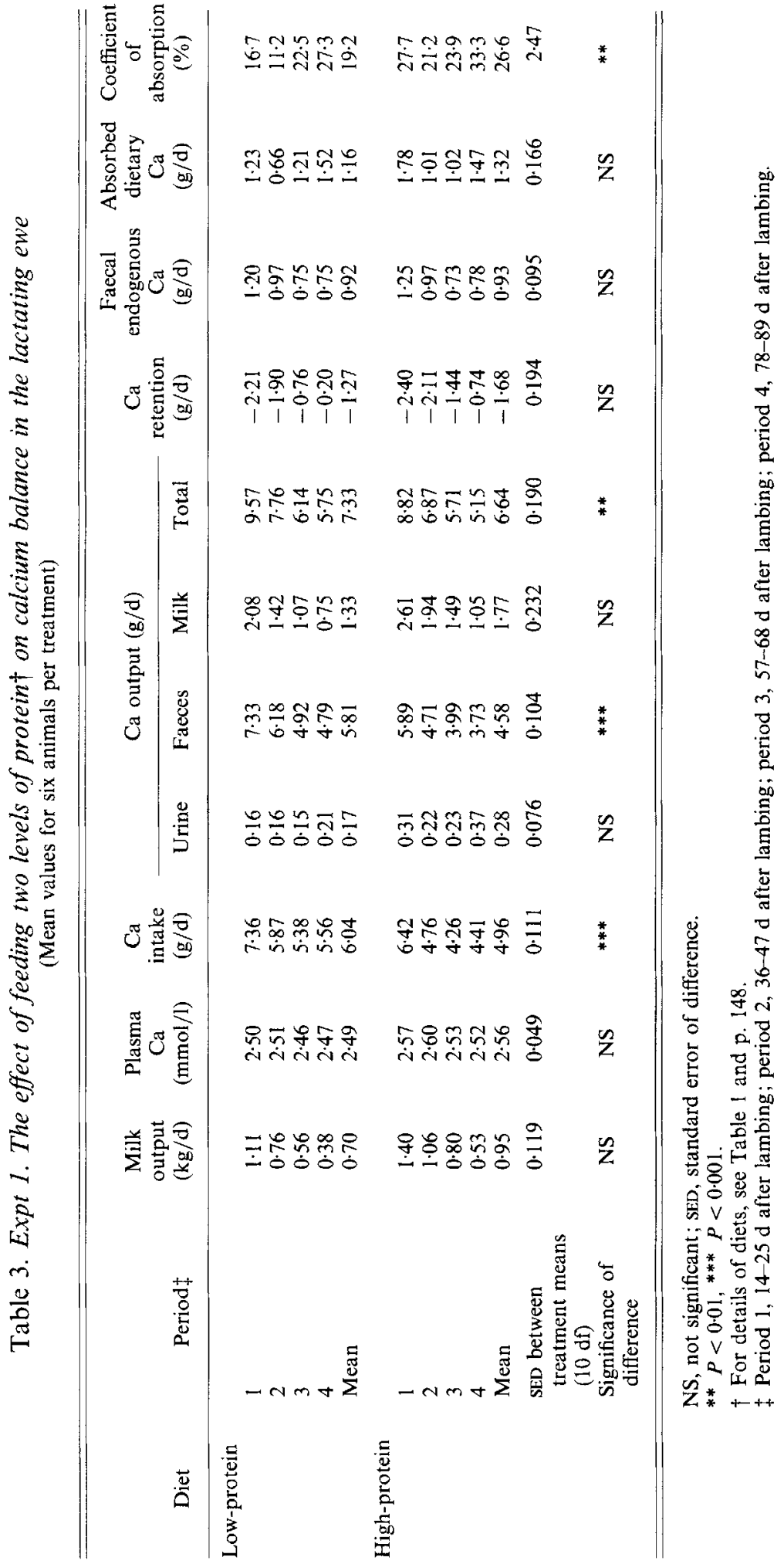




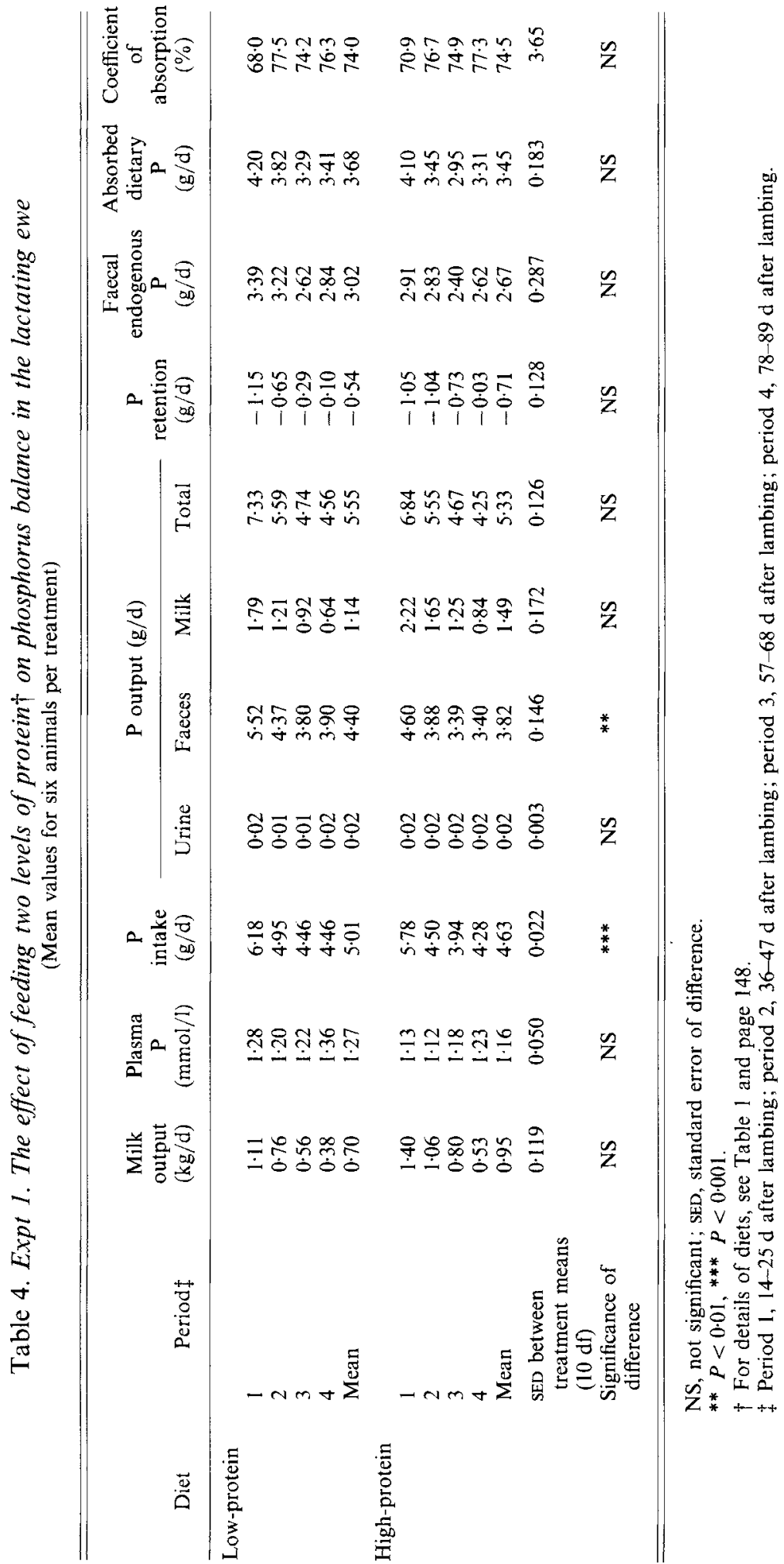


The proportions of faecal $\mathrm{Ca}$ and $\mathrm{P}$ of endogenous origin were calculated from the ratio of the area under the faecal specific radioactivity curve to that under the plasma curve (Field et al. 1982). The faecal data were adjusted to allow for the passage of endogenous mineral through the gut; this was determined as the interval after dosing to the time of collection of faeces having the highest specific radioactivity.

\section{Statistical methods}

Analysis of variance (GENSTAT; Lawes Agricultural Trust, 1984) was used to test the differences between treatments as well as those between periods. Relationships between selected variables were also examined using regression analysis.

\section{RESULTS}

\section{Expt 1}

Table 2 gives mean values for milk yield, $\mathrm{N}$ balance and for the rates of excretion of pyridinoline and deoxy-pyridinoline in the urine of the two groups of ewes.

Milk production varied between individual animals though within each period those fed on the high-protein diet did, on average, excrete a little more milk containing more $\mathrm{N}$ than those fed on the low-protein diet. Faecal $\mathrm{N}$ levels were not affected by dietary protein supply but urine levels were significantly higher $(P<0.01)$ in those fed on the high-protein diet. Average $\mathrm{N}$ retention over the four periods was not significantly affected by dietary protein supply, though there were period differences, with ewes fed on the low-protein diet being in negative $\mathbf{N}$ balance in period 1 and in positive balance in later periods. Ewes fed on the high-protein diet remained in positive $\mathrm{N}$ balance during the first and fourth periods and in near zero $\mathrm{N}$ balance during the second and third periods.

There were no significant treatment differences in either urinary pyridinoline or deoxypyridinoline excretion, with the rates of excretion of both markers being highest in early lactation and showing a progressive decrease in subsequent periods.

Tables 3 and 4 summarize the effects of protein intake on $\mathrm{Ca}$ and $\mathrm{P}$ balance.

Plasma $\mathrm{Ca}$ and $\mathrm{P}$ levels did not differ significantly between treatments and only small amounts of these minerals were excreted in the urine, with the levels excreted being similar for both treatments. Faecal $\mathrm{Ca}$ and $\mathrm{P}$ levels were, however, higher in ewes fed on the lowprotein diet, a difference that probably relates to the higher $\mathrm{Ca}$ and $\mathrm{P}$ content of this diet.

The amounts of $\mathrm{Ca}$ and $\mathrm{P}$ excreted in milk were directly related to milk yield at average concentrations of about 1.9 and $1.6 \mathrm{~g} / \mathrm{kg}$ respectively.

All ewes were in negative $\mathrm{Ca}$ and $\mathrm{P}$ balance throughout the experiment with the amounts lost being directly proportional to milk yield (Fig. 1).

Changing dietary protein supply had no effect on faecal endogenous $\mathrm{Ca}$ or $\mathrm{P}$ excretion nor on the amounts of dietary $\mathrm{Ca}$ or $\mathrm{P}$ absorbed, though in both cases $\mathrm{Ca}$ was absorbed with much lower efficiency than $P$.

\section{Expt 2}

One of the ewes fed on the high $\mathrm{Ca}$-high $\mathrm{P}$ diet became inappetant in late pregnancy and despite treatment had to be withdrawn from the trial.

Tables 5 and 6 give mean values for milk yield and a summary of the $\mathrm{Ca}$ and $\mathrm{P}$ balance data for both sets of ewes. Milk yields were similar to those recorded in Expt 1 and as before both sets of ewes were in negative $\mathrm{Ca}$ and $\mathrm{P}$ balance during both periods of measurement. There was, however, no evidence that alteration in $\mathrm{Ca}$ and $\mathrm{P}$ supply during pregnancy had any effect on either the rates at which these minerals were withdrawn from the skeleton or 


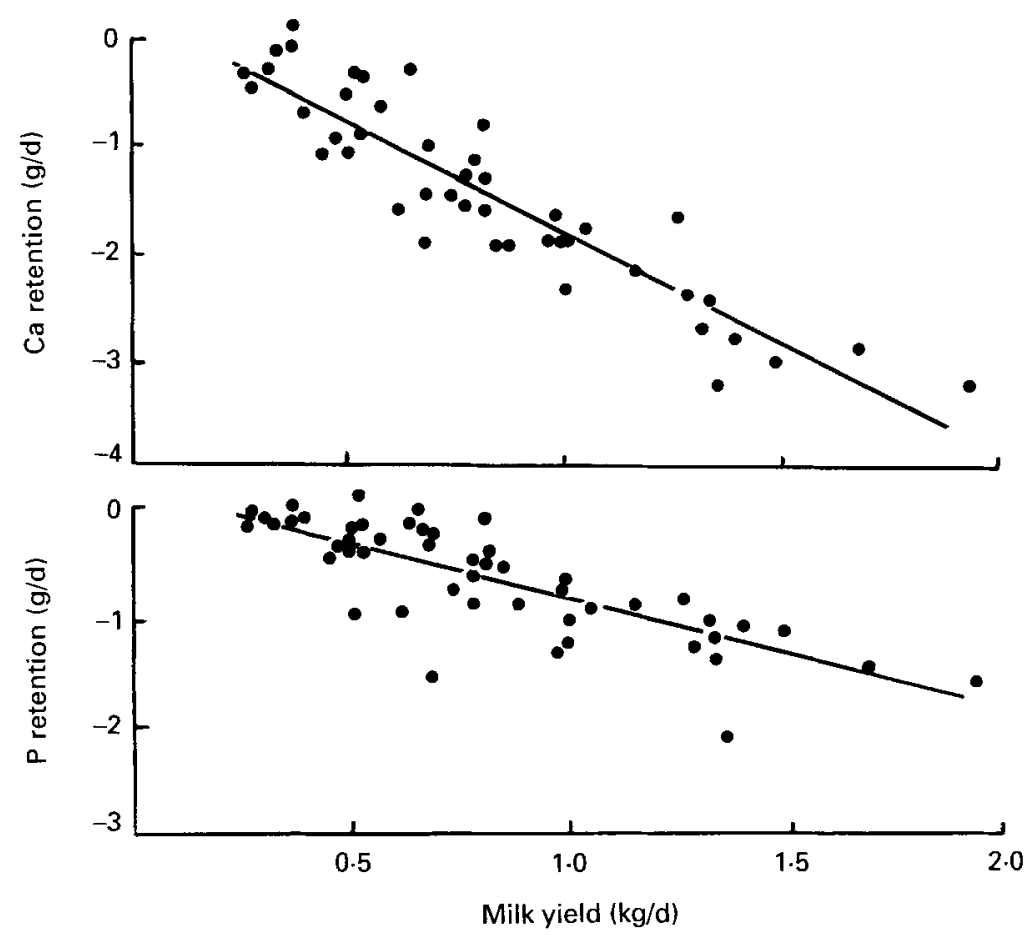

Fig. 1. The relationship between calcium and phosphorus retention and milk yield in the ewe. Included are lines of best fit with:

$$
\begin{array}{rlr}
\text { Ca retention } & =-2.012 \text { yield }(\mathrm{kg} / \mathrm{d})+0.182 & (P<0.001) \\
\mathrm{P} \text { retention } & =-1.059 \text { yield }(\mathrm{kg} / \mathrm{d})+0.213 & (P<0.001)
\end{array}
$$

on the rates at which they were absorbed from the gut, with $\mathrm{Ca}$ again being absorbed with much lower efficiency than $\mathrm{P}$.

\section{DISCUSSION}

Milk yields were lower than expected for ewes of this weight and breed, but were slightly, though not significantly, higher in those fed on the high-protein diet (Table 2). Gonzalez et al. (1982) have previously reported a marked increase in milk yield in response to a range of supplementary proteins, including blood meal, in ewes fed on diets similar in composition to those used in the present trial. The relatively poor response seen here may reflect the fact that their measurements were made using suckling lambs since studies elsewhere have shown that milk yields are lower in ewes that are machine-milked (Treacher, 1970).

Gonzalez et al. (1982) found that the ability of a protein to stimulate milk production was directly related to its degradability in the rumen, with those of low degradability having the greatest effect and with the response to blood meal being comparable to that achieved with fishmeal. Blood meal, which was used here because of its relatively low $\mathrm{Ca}$ and $\mathrm{P}$ content, is known to be somewhat variable in degradability depending on its method of manufacture. This was considered as a possible explanation for its failure to promote milk production but, when tested using the 'nylon-bag' technique (Ørskov et al. 1980), it was found to be almost totally undegradable, with only a $4.9 \%$ loss from the bag after a $96 \mathrm{~h}$ period of incubation in the rumen. Its appearance as additional $\mathrm{N}$ excretion in the urine 


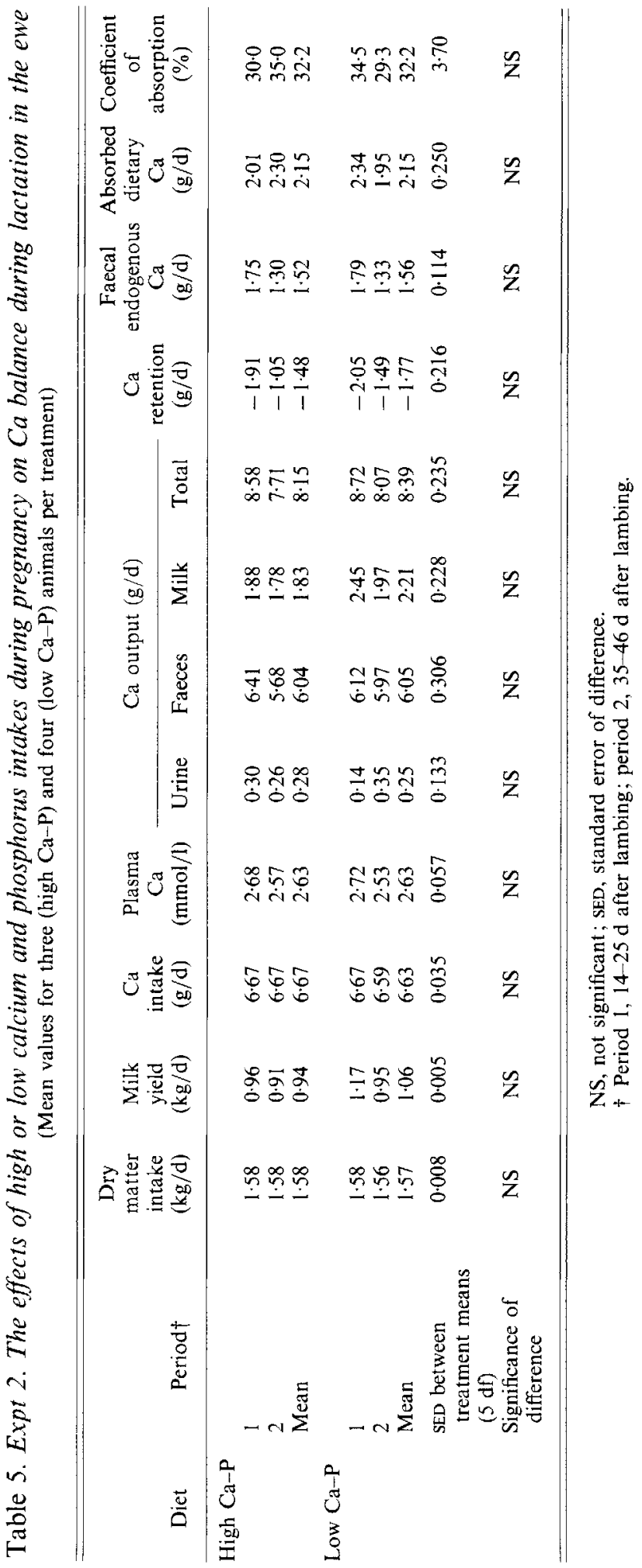


A. A. J. RAJARATNE AND OTHERS

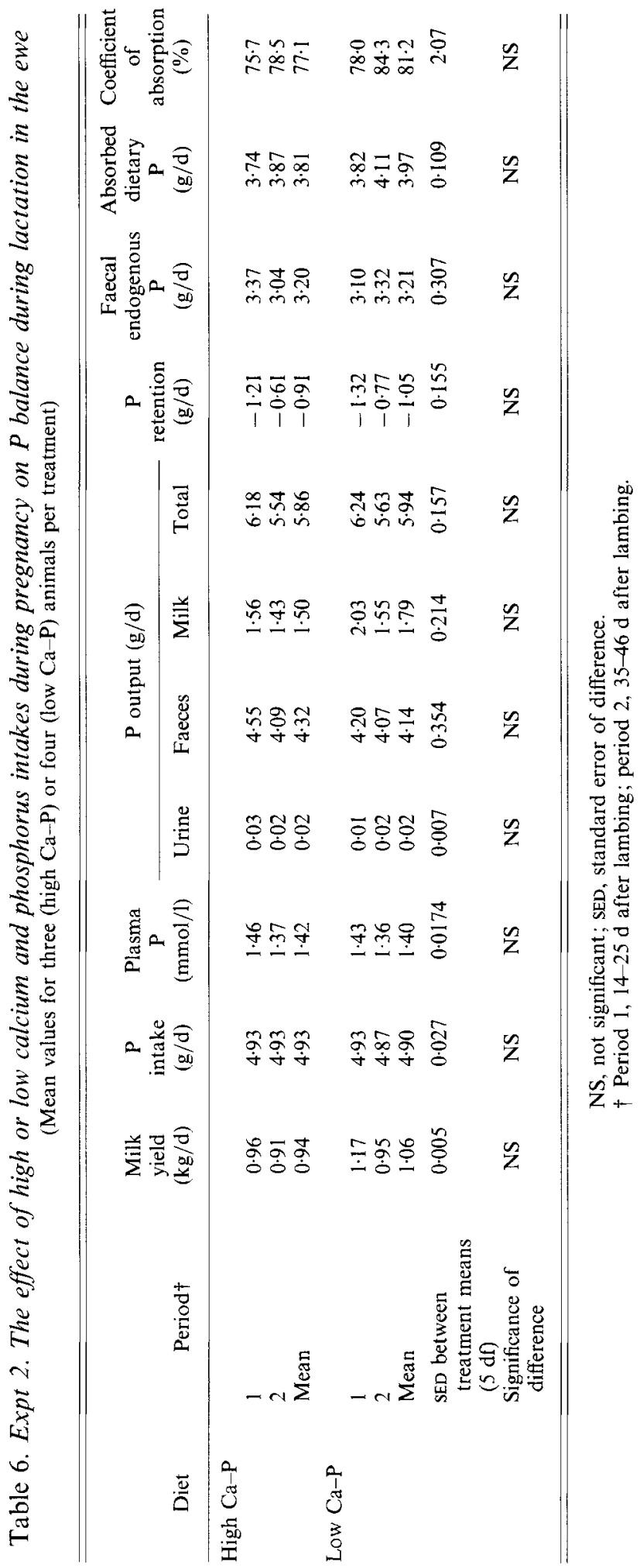


(Table 2) would also seem to remove possible doubts as to its post-rumen digestibility. A shortage of energy was also considered as a possible reason for the poor milk yield and lack of response to protein seen in the present study. Here again, however, this was considered to be an unlikely explanation since daily intakes of $\mathrm{ME}$ were at levels which, according to Agricultural Research Council (1980), would be expected to support a much higher level of milk production than was observed. Again, this would seem to point to machine-milking as the major factor limiting milk production and its response to supplementary protein in the present experiment.

The main object of the present study was not, however, to evaluate blood meal as a protein source but rather to examine the link, if any, between protein deficiency in early lactation and bone mineral resorption by comparing ewes at the same level of mineral intake but at different levels of $\mathrm{N}$ balance. In this respect it was successful with the two groups of ewes showing period differences in $\mathbf{N}$ balance (Table 2) but little difference in mineral balance (Tables 3 and 4). This was most marked in period 1, with ewes fed on the high-protein diet being in positive $\mathrm{N}$ balance while those fed on the low-protein diet were in negative $\mathrm{N}$ balance but with both groups showing a similar degree of negative $\mathrm{Ca}$ and $P$ balance.

Urinary pyridinoline and deoxy-pyridinoline levels were also markedly elevated in period 1 and during each period were excreted in the urine at a ratio of about $10: 1$ (Table 2). This is close to the ratio at which these markers are present in bone (Black et al. 1988) and points to a loss of bone matrix as the source of their increase in excretion. The fact that this increase was common to both groups regardless of their current $\mathrm{N}$ balance position would seem to identify this loss of matrix as being secondary to the withdrawal of mineral from bone in order to meet the mineral requirements for milk production (Fig. 1), rather than mineral loss being secondary to matrix loss due to a shortfall in dietary protein supply. Further evidence to support this view can be seen in recent studies in lactating ewes fed on mixed ryegrass (Lolium perenne)-white clover (Trifolium repens) diets, which were seen to continue losing $\mathrm{Ca}$ from their skeletons over the first 5 weeks of lactation despite being in positive $\mathrm{N}$ balance throughout this period (Chrisp et al. 1989).

What may seem a surprising feature of the present experiment was the low efficiency with which dietary $\mathrm{Ca}$ was absorbed (Table 3), bearing in mind that these ewes were in negative $\mathrm{Ca}$ balance. Braithwaite $(1983 a)$ has also reported similar low efficiencies of absorption of $\mathrm{Ca}$ in ewes in early lactation. Ca absorption is subject to close homeostatic control and hence one might have expected these ewes to have adjusted their absorptive efficiency up to the maximum level $(0 \cdot 68)$, on which both Agricultural Research Council (1980) and TCORN (1990) base their estimates of requirements. Explanations for their failure to do so were therefore considered.

The first of these was a low availability of $\mathrm{Ca}$ in the diet but this was discounted because a major proportion of dietary $\mathrm{Ca}$ was derived from inorganic sources. A second possibility relates to their intakes of $\mathrm{Ca}$ and $\mathrm{P}$ during late pregnancy. The diet at this time in the first experiment was one in general use in this Institute and was high in $\mathbf{C a}$ and $\mathbf{P}$, and towards the end of pregnancy was supplying about 16 and $12 \mathrm{~g} / \mathrm{d}$ of these minerals respectively. Based on recent estimates (Agricultural Research Council, 1980; TCORN, 1990) these intakes would be considered very generous in relation to requirement and it has been suggested that feeding high levels of Ca pre-partum may suppress parathyroid hormone and 1,25(OH)-dihydroxycholicalciferol synthesis (Yarrington et al. 1977). This in turn will favour a reduction in the level of $\mathrm{Ca}$-binding protein in the gut and a consequent decrease in $\mathrm{Ca}$ absorption. Such a reduction in binding protein immediately before the sudden increase in $\mathrm{Ca}$ requirement that follows parturition might be expected to lead to the resorption of mineral from bone. If this were the case then one might expect variation in 
Ca and $P$ supply during pregnancy to influence the amounts of these minerals that are subsequently drawn from the skeleton. It was this concept that Expt 2 was designed to test.

In Expt 2 one group of ewes had $\mathrm{Ca}$ and $\mathrm{P}$ intakes during late pregnancy that were based on the recent TCORN (1990) estimates of requirement $(\mathrm{Ca} 4.3 \mathrm{~g} / \mathrm{d}, \mathrm{P} 3.3 \mathrm{~g} / \mathrm{d}$ ) while the other group had intakes $(\mathrm{Ca} 15.5 \mathrm{~g} / \mathrm{d}, \mathrm{P} 1 \mathrm{l} .4 \mathrm{~g} / \mathrm{d}$ ) similar to those in the first experiment. It is clear, however, from Tables 5 and 6 that this variation in mineral supply during pregnancy had little effect on the subsequent loss of $\mathrm{Ca}$ and $\mathrm{P}$ from the skeleton or on the efficiency with which dietary $\mathrm{Ca}$ was absorbed (Table 5).

This finding was at first puzzling, since it appeared to be at variance with the results of a study reported by Braithwaite (1978) in which during the second half of pregnancy ewes were fed on diets supplying either 8.06 or $1.53 \mathrm{~g} \mathrm{Ca} / \mathrm{d}$ while after parturition both groups were given a diet generous in $\mathrm{Ca}$ and $\mathrm{P}$. Measurements made in early lactation showed a very much higher rate of absorption of $\mathrm{Ca}$ from the gut and a reduced rate of loss from bone in those which were restricted in Ca supply during pregnancy, suggesting that the rate of loss from the skeleton may indeed be affected by supply during pregnancy. However a $\mathrm{Ca}$ intake of $1.53 \mathrm{~g} / \mathrm{d}$ during late pregnancy would by any standards be regarded as inadequate in relation to requirement. A ewe fed on such a diet would be expected to increase its production of intestinal $\mathrm{Ca}$-binding protein, which at the outset of lactation and accompanied by a large increase in $\mathrm{Ca}$ intake would be expected to favour a higher rate of $\mathrm{Ca}$ absorption from the gut and a reduced rate of resorption from bone. If this is so then there may be some subsequent advantage as far as the skeleton is concerned in giving diets during pregnancy that are very low in $\mathrm{Ca}$, though the formulation of such diets may well present practical problems.

Having failed to establish a link between $\mathrm{N}$ and mineral balance in early lactation in the present study, it is uncertain whether or not resorption of mineral from the skeleton at this time is part of an as yet unrecognized hormonal response associated with the onset of lactation. Certainly there is evidence that it is not due to a shortage of $\mathrm{Ca}$ and $\mathrm{P}$ in the diet, in that it has been shown that this loss cannot be prevented simply by increasing dietary $\mathrm{Ca}$ and $\mathrm{P}$ supply (Braithwaite, 1983a,b). Recently a novel parathyroid-hormone-related peptide has been described in patients with hypercalcaemia associated with certain malignancies (Moseley et al. 1987). Preliminary indications are that this peptide is present in fetal blood (Allgrove et al. 1985) and that the messenger RNA for the peptide is also present in a number of adult tissues, including the lactating mammary gland (Thiede \& Rodan, 1988). This has prompted speculation as to its role in the mobilization of bone $\mathrm{Ca}$ and its transfer to milk (Brommage \& De Luca, 1985).

If it does have this role and one were to regard the loss of mineral from bone during early lactation as being to some extent inevitable, then this would also offer an explanation for the low efficiency of $\mathrm{Ca}$ uptake from the gut seen in these and other lactating ewes (Braithwaite, 1983a) in that resorption of mineral from the skeleton would in direct consequence reduce the need to absorb $\mathrm{Ca}$ from the gut. It would also explain the very high levels of endogenous $P$ excreted in the faeces seen in these and in other lactating ewes (Braithwaite, 1983b), the levels in both cases being far higher than those on which the Agricultural Research Council (1980) and TCORN (1990) base their estimates of requirement (Table 4). Resorption of Ca from the skeleton under these conditions will, of course, also lead to a release of $\mathrm{P}$ into the blood. This, when added to that absorbed from the diet, will yield a total supply of $P$ well in excess of that needed to cover milk production (Table 4). One thus has the paradox of an animal that is in negative $P$ balance but which has available to it far more $P$ than it actually requires, resulting in a level of endogenous $\mathrm{P}$ excretion far higher than would be expected in relation to live weight (Agricultural Research Council, 1980) or DM intake (TCORN, 1990). 
Some workers view these levels of endogenous $\mathrm{P}$ excretion as an obligatory loss (Braithwaite, 1983 b) and have argued for an increase in allowances to cover them. This, however, is a view we would not endorse for reasons discussed earlier. Moreover it has no support in practice since feeding supplementary $\mathrm{Ca}$ or $\mathrm{P}$ at this time does not reduce bone mineral loss.

In summary, our results suggest that resorption of $\mathrm{Ca}$ and $\mathrm{P}$ from the skeleton may form part of the normal physiological response of the ewe to the onset of lactation. It appears that this response is largely independent of $\mathrm{N}$ balance and that milk production and the need to meet its mineral requirements provides the major drive in this system.

\section{REFERENCES}

Agricultural Research Council (1980). The Nutrient Requirements of Ruminant Livestock. Farnham Royal: Commonwealth Agricultural Bureaux.

Allgrove, J., Adami, S., Manning, R. M., Chayen, J. \& O'Riordan, J. L. H. (1985). Cytochemical bioassay of parathyroid hormone in maternal and cord blood. Archives of Diseases in Childhood 60, 110-115.

Black, D., Duncan, A. \& Robins, S. P. (1988). Quantitative analysis of pyridinium cross-links of collagen in urine using ion-paited reverse-phase high-performance liquid chromatography. Analytical Biochemistry 169, $197-203$.

Braithwaite, G. D. (1978). The effect of dietary calcium intake of ewes in pregnancy on their Ca and phosphorus netabolism in lactation. British Journal of Nurition 39, 213-218.

Braithwaite, G. D. (1983a). Calcium and phosphorus requirements of the ewe during pregnancy and lactation. 1. Calcium. British Journal of Nutrition 50, $711-722$.

Braithwaite, G. D. (1983b). Calcium and phosphorus requirements of the ewe during pregnancy and lactation. 2. Phosphorus. British Journal of Nutrition 50, 723-736.

Braithwaite, G. D., Glascock, R. F. \& Riazuddin, S. H. (1969). Calcium metabolism in lactating ewes. British Journal of Nutrition 23,827-833

Brommage, R. \& De Luca, H. F. (1985). Regulation of bone mineral loss during lactation. American Journal of Physiology 248, E182-E187.

Chrisp, J. S., Sykes, A. R. \& Grace, N. D. (1989). Kinetic aspects of calcium metabolism in lactating sheep offered herbages with different Ca concentrations and the effect of protcin supplementation. Briish Journal of Nutrition 61, $45-58$

Davidson, J., Mathieson, J. \& Boyne, A. W. (1970). The use of automation in determining nitrogen in the Kjehidahl method with final calculation by computer. Analyst 95, 181-183.

Field, A. C., Coop, R. L., Dingwall, R. A. \& Munro, C. S. (1982). The phosphorus requirements for growth and maintenance of sheep. Journal of Agricultural Science, Cambridge 99, 31 I-317.

Field, A. C., Kamphues, J. \& Woolliams, J. A. (1983). The effect of dietary intake of calcium and phosphorus on the absorption and excretion of phosphorus in chimaera-derived sheep. Journal of Agricultural Science, Cambridge 101, 597-692.

Forbes, J. M. (1977). Interrelationships between physical and metabolic control of voluntary food intake in fattening, pregnant and lactating sheep: a model. Animal Production 24, 91101.

Gitelman, H. J. (1967). An improved automated procedure for the determination of calcium in biological fluids. Analytical Biochemisty 18, $52 !-531$.

Gonzalez, J. S., Robinson, J. J., McHattic, 1. \& Fraser, C. (1982). The effect in ewes of source and level of dietary protein on milk yield, and the relationships between the intestinal supply of non-ammonia nitrogen and the production of milk protein. Animal Production 34, 31-40.

Lawes Agricultural Trust (1984). Genstat V.Mark 4.01, Rothampstead Experimental Station, Harpenden, Hertfordshire.

Moseley, J. M., Kubota, M., Diefenbach-Jagger, H., Wettenhall, R. E. H., Kemp, B. E., Suva, L. J., Rodda, C. P., Ebeling, P. J., Hudson, J. D., Zajac, J. D. \& Martin, T. J. (1987). Parathyroid hormone-related protein purified from a human lung cancer cell line. Proceedings of the National Academy of Science, USA 84, $5048-5052$.

Orskov, E. R., Hovell, F. D. DeB. \& Mould, F. (1980). The use of the nylon bag technique for the evaluation of feedstuffs. Tropical Animal Production 5, 195-213.

Ramberg, C. F. Jr, Mayer, G. P., Kronfeld, D. S., Phang, J. M. \& Berman, M. (1970). Calcium kinetics in cows during late pregnancy, parturition and early lactation. American Journal of Physiology 219, 1166-1177.

Roach, A. G. (1965). Application of Technicon autoanalyzer equipment to the routine determination of calcium and phosphorus in animal feedstuffs. In Automation in Analytical Chemistry, Technicon Symposia, pp. 137-141 [L. T. J. Skeggs, editor]. New York: Mediad Incorporated.

Sykes, A. R. \& Geenty, K. G. (1986). Calcium and phosphorus balances of lactating ewes at pasture. Journal of Agricultural Science, Cambridge 109, 357-364. 
TCORN (1990). A reappraisal of the calcium and phosphorus requirements of sheep and cattle. Nutrition Abstracts and Reviews (In the Press).

Thiede, M. A. \& Rodan, G. A. (1988). Expression of a Calcium-mobilizing parathyroid hormone-like peptide in lactating mammary tissue. Science 242, 278-280.

Treacher, T. T. (1970). Apparatus and milking techniques used in lactation studies with sheep. Journal of Dairy Research 37, 289-295.

Yarrington, J. T., Capen, C. C., Black, H. E. \& Re, R. (1977). Effects of a low Ca prepartal diet on calcium homeostasis mechanisms in the cow. Morphological and Biochemical studies. Journal of Nutrition 107, 22442256.

Young, D. S. (1966). An improved method for the automatic determination of serum inorganic phosphate. Journal of Clinical Pathology 19, 397-399. 